\title{
REAKTUALISASI PENGAMALAN NILAI PANCASILA UNTUK DEMOKRASI INDONESIA
}

\begin{abstract}
Mutiani
Universitas Lambung Mangkurat

Email: ulunmutiani@gmail.com

Naskah diterima: 10 Agustus 2015, direvisi: 13 November 2015, disetujui: 12 Desember 2015

Abstract

Pancasila as an integral (comprehensively) is a solid supporting to the state established in Indonesia. Pancasila is maintained and developed with the aim to protect and develop the dignity and rights of all citizens of the nation to democracy in Indonesia. Posts in this article aims to explain how the urgency of re-actualization of Pancasila. As a method of this paper is literature study. The writer was conducting Pancasila in the context of political education in Indonesia emphasis on understanding the unity and integrity of the nation and the values listed in UUD 1945 with its main foundation of Pancasila. As the result, therefor, Pancasila is expected to realize the Good and Smart Citizenship, which, law-abiding citizens, to the literacy of citizens to political issues.

Keywords: Pancasila; Indonesia democracy; political awareness

Abstrak

Pancasila sebagai nilai-nilai integral yang melandasi kehidupan bangsa dan Negara Indonesia. Pancasila dikembangkan dan dipertahankan dengan tujuan untuk melindungi dan mengembangkan hak, kewajiban, harkat, dan martabat seluruh warga negara, terutama dalam menerapkan sistem demokrasi di Indonesia. Artikel ini bertujuan untuk menjelaskan bagaimana urgensi aktualisasi Pancasila dalam kehidupan bangsa dan negara Indonesia. Untuk tujuan tersebut penulis melakukan metode studi pustaka. Artikel ini difokuskan pada reaktualisasi nilai-nilai Pancasila dalam konteks pendidikan politik di Indonesia untuk membangun pemahaman tentang pentingnya nilai-nilai persatuan dan kesatuan bangsa serta untuk membangun kesadaran politik dalam kehidupan bangsa dan negara Indonesia.
\end{abstract}

Kata kunci: Pancasila; demokrasi Indonesia; kesadaran politik

Pengutipan: Mutiani. (2015). Reaktualisasi Pengamalan Nilai Pancasila untuk Demokrasi Indonesia. SOSIO DIDAKTIKA: Social Science Education Journal, 2(2), 2015, 176-183. doi:10.15408/sd.v2i2.2822.

Permalink/DOI: http://dx.doi.org/10.15408/sd.v2i2.2822 


\section{A. Pendahuluan}

Setiap negara tentunya memiliki landasan politik yang akan selalu dipegang teguh untuk menggerakkan roda pemerintahan. Landasan politik merupakan sebuah dasar pijakan bagi arah politik negara. Bagi Indonesia, Pancasila tidak hanya dipandang sebagai landasan politik tetapi juga sebuah mahakarya dari para jenius tokoh bangsa. Dalam runtutan proses pemunculan pemikiran, Pancasila muncul setelah melalui fase pembuahan, perumusan, dan pengesahan. Kini, Pancasila menjelma sebagai dasar negara yang dianut oleh bangsa dan negara Indonesia hingga sekarang.

Pada sisi yang lain, Pancasila sebagai ideologi negara Republik Indonesia merupakan ideologi yang terbuka. Ideologi terbuka merupakan sistem pemikiran terbuka yang memiliki karakteristik bahwa nilai-nilai dan ciriciri yang akan diwujudkan tidak bisa dipaksakan dari luar, tetapi digali dan diambil dari moral maupun tata nilai budaya masyarakat itu sendiri. ${ }^{1}$ Dasarnya bukan dari keyakinan sekelompok orang, melainkan hasil kesepakatan masyarakat Indonesia secara keseluruhan. Oleh sebab itu, ideologi terbuka bukan ciptaan negara, melainkan digali dan ditemukan masyarakat atau bangsa itu sendiri melalui proses yang panjang, intensif, menyeluruh, dan terpadu. Dengan demikian ideologi terbuka menjadi milik semua komponen bangsa.

Nilai-nilai luhur yang terkandung di dalam Pancasila merujuk pada paradigma pembangunan makro ataupun mikro yang dimiliki oleh Republik Indonesia, acuan terhadap tahap-tahap amandemen UUD 1945, serta perilaku konstitusional dalam kehidupan berbangsa dan bernegara. ${ }^{2}$ Akan tetapi, kekinian Pancasila telah memasuki sebuah dimensi kritis. Sebuah dimensi di mana kita lupa akan kekuatan "magis" apa yang dimiliki Pancasila. Disadari ataupun tidak, kekuatan ini dapat merangkul konsepsi demokrasi yang mulai diterapkan oleh Republik Indonesia. Penerapan sistem demokrasi di Republik Indonesia merupakan sebuah cerminan kemajemukkan

\footnotetext{
1 Yudi Latif. Negara Paripurna: Historisitas, Rasionalitas, Dan Aktualitas Pancasila (Jakarta: Pustaka Gramedia, 2011), h. 34

2 Winarno. Paradigma Baru Pendidikan Kewarganegaraan (Jakarta: Bumi Aksara 2008), h. 87
}

semua golongan untuk menyerukan hidup berdampingan satu sama lain tanpa adanya diskriminasi ras maupun golongan. ${ }^{3}$ Oleh karena itu, semestinya keselarasan nilai-nilai Pancasila dapat mewujudkan sistem demokrasi bagi Republik Indonesia.

\section{B. Pancasila dalam Perspektif Historis}

Indonesia muncul sebagai sebuah bangsa dan negara dimulai dari keberanian suatu komunitas imaginer. Komunitas Imajiner merupakan segala komunitas yang lebih luas dari pada desa-desa dengan kontak tatap muka adalah imajinasi. ${ }^{4}$ Sebuah komunitas yang bisa dipahami sebagai perserikatan yang dalam, horizontal, dan membangun semacam hubungan persaudaraan antara anggotanya. Imajinasi kemerdekaan telah merasuk ke dalam relung hati para pejuang guna mewujudkan sebuah negara idaman. Akar kultural yang mendekati sifat religius menopang komunitas imajiner, seperti halnya agama yang selalu memiliki jawaban tentang eksistensial manusia: kehidupan dan kematian. Sebuah pemikiran yang kemudian dianalogikan kepada konsep kebangsaan. Kebangsaan menawarkan hal serupa dengan konsep keagamaan, yakni rasa kontinuitas di hadapan diskontinuitas. Sebuah rasa di mana kita semua mampu menghirup udara kebebasan hakiki dan hidup sebagai warga negara yang harmonis.

Kesepakatan akan sebuah persatuan diikat dalam konsep nasionalisme. Sebagaimana kita ketahui bahwa nasionalisme Indonesia secara kolektif kita kenal sejak era pergerakan nasional. Tahun 1908, organisasi Boedi Oetomo muncul menyerukan gerakan nasionalis. Ruang gerak organisasi Boedi Oetomo awalnya terbatas pada gerakan etnisitas Jawa, akan tetapi kepeloporan gerakan tersebut telah memberikan imajinasi baru bagi beberapa organisasi di era pergerakan nasional untuk mewujudkan kemerdekaan Indonesia. Pembentukan masyarakat yang terikat secara horizontal (atau menurut istilah Anderson "conceptually egalitarian"), setara pada tataran konsep. Konsep baru mensyaratkan

\footnotetext{
3 Ehrenhalt. Demokrasi Dalam Cermin: Politik. Akar Rumput dan Reformasi di Amerika Serikat (Jakarta: Yayasan Obor, 2006), h. 101.

4 Benedict Anderson. Imagined Communities: Reflection on the Origin and Spread of Nationalism (Yogyakarta: Pustaka Pelajar \& Insist Press, 2002), h. 56.
} 
reformasi sosial dan politis yang cukup besar. ${ }^{5}$ Reformasi memunculkan sebuah dampak sosial yang lebih luas. Adapun contohnya antara lain: kesetaraan pendidikan dan politis guna membangkitkan patriotisme. Pembangunan kesadaran solidaritas horizontal dan egaliter menjadi pola awal pemikiran konsep Pancasila pasca kemerdekaan.

Konsep ideologi politik Indonesia secara konkrit muncul sejak tahun 1924. Perhimpunan Indonesia (PI) di Belanda memaparkan tujuan kemerdekaan politik mengacu pada empat prinsip, yakni persatuan nasional, solidaritas, non-koperasi, dan kemandirian (self-help). ${ }^{6}$ Keempat prinsip tersebut terus dikembangkan menjadi usaha intelektual untuk mencari sintesis elemen keindonesiaan, yakni "Sumpah Pemuda" tanggal 28 Oktober 1928. Sumpah Pemuda mempertautkan visi keberagaman dalam kesatuan tanah air, bangsa, dan bahasa.

Dalam kenyataan, Indonesia mengenal dua golongan dominan: golongan kebangsaan dan golongan Islam. Akan tetapi, pertautan geneologis dan kesatuan geo-politik pada masing-masing pendukung aliran, kemudian memahami titik persamaan substansif setiap prinsip. Pada tahapan perumusan Pancasila, kedua golongan tersebut berbesar hati datang guna merumuskan Pancasila dalam forum Badan Penyelidik Usaha Persiapan Kemerdekaan Indonesia (BPUPKI). Pada sidang pertama BPUPKI tanggal 29 Mei - 1 Juni 1945, dasar negara Indonesia mulai dirumuskan. BPUPKI memiliki tugas sebagai pelaku usaha-usaha penyelidikan kemerdekaan. Guna melengkapi proses persiapan kemerdekaan, maka dibentuklah Panitia Persiapan Kemerdekaan Indonesia (PPKI). PPKI kemudian secara resmi memiliki tugas sebagai penyusun rancangan dan penetapan Undang-Undang Dasar (UUD). Akan tetapi, semua itu hanya sebuah skenario awal karena para pemimpin bangsa berani menerobos batas formalitas melalui kreativitas.

Ir. Soekarno memaparkan bahwa dasar negara Indonesia mengacu pada kerangka "dasar falsafah ataupun pandangan dunia" dengan penjelasan yang runut, solid, dan koheren.
Kelima dasar negara kemudian disebut beliau dengan istilah Panca (lima) dan Sila (dasar). Dalam lintasan proses konseptualisasi Pancasila resmi dilahirkan tanggal 1 Juni 1945. Akan tetapi, sebagai dasar negara Pancasila harus mendapatkan persetujuan kolektif melalui pembahasan mendalam oleh Panitia Kecil yang berjumlah 9 orang yang berhasil menyepakati perumusan Piagam Jakarta pada tanggal 22 Juni 1945. Akhirnya, rumusan akhir Piagam Jakarta dilakukan pengesahan melalui proses konstitusional pada 18 Agustus 1945.7 Oleh karena itu, rumusan Pancasila sebagai dasar negara yang secara konstitusional dan mengikat kehidupan kebangsaan hingga kenegaraan Indonesia adalah rumusan Pancasila pada 18 Agustus 1945.

Seluruh proses konseptualisasi telah melibatkan berbagai unsur dan golongan. Hal ini mensintesiskan bahwa Pancasila adalah karya bersama yang harus terus dijaga sebagai representasi keutuhan dasar negara Republik Indonesia.

\section{Problematika Demokrasi Indonesia}

Konsepsi demokrasi merupakan bahan perbincangan hangat di kalangan masyarakat sipil, militer, hingga politisi. Pasca reformasi 1998, demokrasi bukanlah hal yang ambigu karena kran ini telah terbuka seluas-luasnya untuk mengakses informasi oleh rakyat atas jalannya pemerintahan. Penerapan demokrasi di Indonesia tidak bisa dipungkiri telah menghasilkan kemajuan yang cukup berarti dari aspek prosedural, seperti: pemilu legislatif, pemilihan kepala daerah, hingga presiden dan wakil presiden. ${ }^{8}$ Aspek prosedural pemilihan wakil pemerintahan yang diterapkan oleh Indonesia berjalan lancar, transparan, demokratis, dan tidak menimbulkan kisruh di kalangan masyarakat. Demokrasi pun akhirnya mampu melepaskan belenggu komunikasi yang mengikat rakyat terhadap pemerintah pada Orde Baru, yakni: kebebasan berpendapat (freedom of exploration), kebebasan berserikat (freedom of assembly), dan kebebasan pers (freedom of press). ${ }^{9}$

Yudi Latif, Ibid, h. 47-51.

8 Kacung Marijan, Sistem Politik. Indonesia: Konsolidasi Demokrasi Pasca Orde Baru (Jakarta: Kencana, 2010), h. 18-21.

9 As'ad, Negara Pancasila: Jalan Kemaslahatan Berbangsa (Jakarta: Pustaka LP3ES, 2009), h. 99 
Serangkaian nilai-nilai yang diyakini secara akademis dan empiris sebagai "core values of democracy" sebagaimana yang berlaku di negara maju dan memperoleh pengakuan dari PBB, antara lain:

1. Prinsip pemerintahan berdasar konstitusi (baru) yang menjamin checks and balances yang sehat.

2. Pemilihan umum yang demokratis (free and fair), yang pada akhirnya telah mengembalikan kedaulatan sepenuhnya kepada rakyat.

3. Desentralisasi kekuasan dan tanggung jawab atas dasar sistem otonomi daerah untuk lebih mendekatkan rakyat pada pengambilan keputusan.

4. Sistem pembuatan undang-undang yang demokratis, aspiratif, dan terbuka prosesnya.

5. Sistem peradilan yang independen, yang bebas dari tekanan atau pengaruh dari manapun datangnya.

6. Pembatasan kekuasaan kepresidenan atas dasar konstitusi.

7. Peran media yang bebas sebagai sarana kontrol sosial.

8. Jaminan terhadap peran kelompokkelompok kepentingan (civil society).

9. Hak masyarakat untuk tahu.

10. Promosi dan perlindungan HAM, termasuk perlindungan hak-hak minoritas karena beda agama, ras, atau etnis.

11. Kontrol sipil terhadap militer.

Dalam konteks yang lebih khusus, demokrasi Indonesia diwujudkan dalam pengamalan nilainilai Pancasila. Hal ini kemudian memunculkan konsepsi baru yakni demokrasi Pancasila. Demokrasi Pancasila adalah demokrasi yang berdasar pada asas kekeluargaan dan gotong royong yang ditujukan bagi kesejahteraan rakyat. Di dalamnya mengandung unsur kesadaran beragama, kebenaran, kecintaan, kasih sayang, berbudi pekerti, berkesinambungan, dan berkepribadian Indonesia. Dardji Darmodiharjo menjelaskan bahwa demokrasi Pancasila adalah paham demokrasi yang bersumber kepada kepribadian dan falsafah hidup bangsa Indonesia, yang perwujudannya seperti dalam ketentuan-ketentuan Pembukaan UUD 1945, bahwa pengertian demokrasi Pancasila dapat dibedakan atas:

1. Aspek material (segi substansi/isi), demokrasi Pancasila harus dijiwai dan diintegrasikan oleh sila-sila lainnya. Karena itulah, pengertian demokrasi Pancasila tidak hanya merupakan demokrasi politik, tetapi juga demokrasi ekonomi dan sosial.

2. Aspek formal, demokrasi Pancasila merupakan bentuk atau cara pengambilan keputusan (demokrasi politik) yang dicerminkan oleh sila keempat, yakni "Kerakyatan yang dipimpin oleh hikmat kebijaksanaan dalam permusyawaratan/ perwakilan".

Secara keseluruhan, demokrasi Pancasila diharapkan mampu menjembatani segala kepentingan mengarah kepada kepentingan masyarakat, bukan kelompok tertentu. Namun, bagai mata uang yang selalu berdampingan, kemajuan demokrasi Indonesia pun memunculkan beberapa problematika dalam praktik demokrasi. Permasalahan demokrasi yang ada perlu dikelompokkan lagi menjadi tiga hal, yaitu: (1) partisipasi politik, (2) etika politik, dan (3) sistem demokrasi secara keseluruhan.

Pertama, peranan masyarakat dalam menciptakan demokrasi sangat ditentukan oleh partisipasi politiknya. Namun demikian tidak semua anggota masyarakat dapat memberikan partisipasi politiknya. Penyebab dari rakyat yang tidak mampu memberikan partisipasi politiknya adalah karena tidak adanya peluang untuk berpartisipasi, atau karena terbatasnya kemampuannya untuk berpartisipasi dalam politik. Rakyat memiliki tanggung jawab kepada negara dengan cara mengambil peranan dalam partisipasi politik. Hal ini mengacu pada kewajiban rakyat yang memiliki peran sebagai pengontrol dari pemerintah terhadap kebijakankebijakan yang diambil pemerintah. ${ }^{10}$ Pada saat sekarang ini, peluang rakyat untuk berpartisipasi 
politik sebenarnya cukup lebar. Saat sekarang telah banyak berdiri partai-partai politik di Indonesia. Partai-partai politik ini berfungsi sebagai salah satu wadah untuk menyalurkan partisipasi politik. Selain itu ikut dalam pemilihan umum yang diadakan tiap lima tahun sekali merupakan salah satu dari partisipasi politik rakyat. Namun, saat ini terjadi masalah-masalah yang mengakibatkan rendahnya partisipasi rakyat dalam politik, seperti pendidikan yang rendah menyebabkan rakyat kurang aktif dalam melaksanakan partisipasi politik.

Kedua, demokrasi dipandang dari segi etika politiknya. Secara subtantif pengertian etika politik tidak dapat dipisahkan dengan subyek sebagai pelaku etika, yaitu manusia. Oleh karena itu etika politik berkait erat dengan bidang pembahasan moral. Hal ini berdasarkan kenyataan bahwa pengertian moral senantiasa menunjuk kepada manusia sebagai subyek etika. Walaupun dalam konteks politik berkaitan erat dengan masyarakat, bangsa dan negara, etika politik tetap meletakkan dasar fundamental manusia sebagai manusia. Dasar ini lebih meneguhkan akar etika politik bahwa kebaikan senantiasa didasarkan kepada hakikat manusia sebagai makhluk yang beradab dan berbudaya.

Pemilihan umum di Indonesia merupakan arena pertarungan antara aktor-aktor yang haus akan popularitas dan kekuasaan. Sebagian besar petinggi pemerintahan di Indonesia adalah orang-orang yang sangat pandai mengumbar janji untuk memikat hati rakyat. Menjelang pemilihan umum, mereka akan mengucapkan berbagai janji mengenai tindakan-tindakan yang akan mereka lakukan apabila terpilih dalam pemilu, mereka berjanji untuk mensejahterakan rakyat, meringankan biaya pendidikan dan kesehatan, mengupayakan lapangan pekerjaan bagi rakyat, dan sebagainya. Tidak hanya janjijanji yang mereka gunakan untuk mencari popularitas di kalangan rakyat, melainkan mereka juga melakukan tindakan money politics. Perbuatan tersebut adalah perbuatan yang tidak bermoral dan melanggar etika politik. Hak pilih yang merupakan hak asasi manusia tidak bisa dipaksakan oleh orang lain, namun melalui money politics ssecara tidak langsung mereka mempengaruhi seseorang dalam penggunaan hak pilihnya. Selain itu, perbuatan para calon petinggi pemerintahan tersebut juga melanggar prinsip pemilu yang langsung, umum, bebas, rahasia, jujur, dan adil.

Ketiga, permasalahan demokrasi dipandang dari segi sistemnya secara keseluruhan, mencakup infrastruktur dan suprastruktur politik di Indonesia. Infrastruktur politik adalah mesin politik yang berasal dari kekuatan riil masyarakat, seperti partai politik (political party), kelompok kepentingan (interest group), kelompok penekan (pressure group), media komunikasi politik (political communication media), dan tokoh politik (political figure). ${ }^{11}$ Disebut sebagai infrastruktur politik karena mereka termasuk pranata sosial dan yang menjadi konsentrasi masing-masing kelompok adalah kepentingan kelompok mereka masing-masing.

Dalam pelaksanaan demokrasi, harus ada hubungan atau relasi yang seimbang antara komponen yang ada. Tugas, wewenang, dan hubungan antarlembaga negara itu pun diatur dalam UUD 1945. Relasi atau hubungan yang seimbang antarlembaga dalam komponen infrastruktur maupun suprasruktur politik (eksekutif, legislatif, dan yudikatif yang merupakan elit pemerintah) harus mampu menghasilkan suatu keteraturan kehidupan politik dalam sebuah negara. Namun tetap saja, penyimpangan dan permasalahan itu selalu ada dalam kehidupan masyarakat yang beragam dan senantiasa berubah seiring waktu.

Dalam lembaga legislatif (DPR) misalnya, sebagai lembaga yang dipilih oleh rakyat dan kedudukannya adalah sebagai wakil rakyat yang sebisa mungkin harus memposisikan diri sebagai penyambung lidah rakyat, megingat pemegang kekuasaan tertinggi dalam negara demokrasi adalah rakyat (kedaulatan rakyat). Namun dalam pelaksanaannya, lembaga negara tidak memposisikan diri sebagai penyampai aspirasi rakyat dan representasi dari kehendak rakyat untuk mencapai kesejahteraan, melainkan justru lembaga negara tersebut sebagai pemegang kekuasaan dalam sebuah negara, dan rakyat harus tunduk terhadap kekuasaan tersebut.

11 Syamsuddin Haris, Praktik Parlementer Demokrasi Presidensial Indonesia (Yogyakarta: Andi Publisher, 2014), h. 44. 


\section{Urgensi Pendidikan Politik bagi Rakyat Indonesia}

Pendidikan politik sebagai sebuah kegiatan pendidikan memiliki fokus tidak hanya terbatas pada keyakinan semata. ${ }^{12}$ Namun anak harus mampu menggambarkan prosedur berdasarkan atas apa yang mereka dapat pada perilaku politik. Proses ini didapat dari akumulasi pengetahuan yang spesifik dan cara menyampaikan "politik" oleh indivdu lain, seperti guru, orang tua, ataupun figur lain. Secara historis pendidikan politik mengandung tiga tahapan sistematis yang berkaitan satu sama lain, yakni: (1) patriotic/ traditional political education, (2) institutional political education, dan (3) behavioristic political education.

Pertama, tahapan patriotic/traditional political education, yakni merupakan sebuah penekanan pada kebutuhan "nation and character building", sebagai landasan dan syarat objektif semua negara. ${ }^{13}$ Dalam tahapan ini, praktiknya adalah saat pencapaian kemerdekaan bangsa sehingga pertentangan politik tidak bisa diindahkan bahkan pemberontakkan dengan mengangkat senjata pun hampir dialami oleh semua bangsa. Selain itu, menekankan penanaman nilai-nilai tertentu yang dilakukan melalui indoktrinasi dan aksositori.

Kedua, institutional political education, yakni tahapan di mana pendidikan politik membicarakan mengenai hubungan warga negara dengan pemerintah dalam kehidupan bermasyarakat dan bernegara. Dalam jenis pendidikan politik ini, peserta didik (warga negara) diarahkan menjadi seseorang warga negara yang baik, terutama peran serta dan tanggung jawabnya dalam rumah tangga masyarakat/negara, mula dari unit terkecil (keluarga) hingga pergaulan dunia internasional. Teori demokrasi menjadi pusat perhatian pendidikan politik pada tahapan ini. Ketika mengkaji hubungan warga negara dengan lembaga-lembaga negaranya praktis hampir tidak terdapat kesulitan, sebab segalanya sesuatu sudah diatur oleh UUD 1945 dan perundangundangan lainnya.

\footnotetext{
12 Robert Brownhill dan Patricia Smart, Political Education (London and New York: Routledge, 1989), h. 64-65.

13 Nu'man Somantri, Menggagas Pembaharuan Pendidikan IPS (Bandung: Remaja Rosda Karya, 2001), h. 229-231.
}

Ketiga, pendidikan politik pada tahapan behavioristic political education, yakni pendidikan politik mengkaji mekanisme dan nilai-nilai serta perilaku kelompok-kelompok masyarakat yang beraneka ragam dan perilaku pemerintah dalam arti luas. Wajah pendidikan politik di Indonesia merupakan sintesis dari ketiga tahapan tersebut. Konteks pendidikan politik Indonesia saat ini menekankan pada pemahaman kesatuan dan persatuan bangsa dan nilai-nilai yang tercantum dalam UUD 1945 dengan landasan utamanya Pancasila. Ketiganya merupakan kerangka pendukung tumbuhnya kualitas manusia Indonesia seperti tercantum dalam rumusan tujuan pendidikan nasional yang tercantum pada UU No. 20/1989 tentang Sistem Pendidikan Nasional. Good and smart citizenship yang diusung melalui pendidikan politik diharapkan mampu memunculkan political awareness, warga negara taat hukum, hingga literasi warga negara terhadap persoalan politik.

\section{E. Pengamalan Nilai-nilai Pancasila bagi Rakyat Indonesia}

Penetapan Pancasila sebagai dasar negara memberikan pengertian bahwa negara Republik Indonesia adalah negara Pancasila. Hal itu mengandung arti bahwa negara harus tunduk kepadanya, serta membela dan melaksanakannya dalam seluruh perundang-undangan. Negara Pancasila adalah suatu negara yang didirikan, dipertahankan, dan dikembangkan dengan tujuan untuk melindungi dan mengembangkan martabat dan hak-hak azasi semua warga bangsa Indonesia (kemanusiaan yang adil dan beradab), agar masing-masing dapat hidup layak sebagai manusia, mengembangkan dirinya dan mewujudkan kesejahteraannya lahir batin selengkap mungkin, memajukan kesejahteraan umum, yaitu kesejahteraan lahir batin bagi seluruh rakyat, dan mencerdaskan kehidupan bangsa (keadilan sosial). ${ }^{14}$

Pandangan tersebut melukiskan Pancasila secara integral (utuh dan menyeluruh) sehingga merupakan penopang yang kokoh terhadap negara yang didirikan di atasnya, dipertahankan, dan dikembangkan dengan tujuan untuk 14 Edward S. Greenberg, Political Socialization (United State Of Ameri-
ca: Aldine Transaction, 2009), h. 77. 
melindungi dan mengembangkan martabat dan hak-hak azasi semua warga bangsa Indonesia. Perlindungan dan pengembangan martabat kemanusiaan itu merupakan kewajiban negara, yakni dengan memandang manusia qua talis, manusia adalah manusia sesuai dengan principium identitasnya. Pancasila seperti yang tertuang dalam Pembukaan UUD 1945 dan ditegaskan keseragaman sistematikanya melalui Instruksi Presiden No.12 Tahun 1968 itu tersusun secara hirarkis-piramidal. Setiap sila (dasar/ azas) memiliki hubungan yang saling mengikat dan menjiwai satu sama lain sedemikian rupa hingga tidak dapat dipisah-pisahkan. Melanggar satu sila dan mencari pembenarannya pada sila lainnya adalah tindakan sia-sia. Oleh karena itu, Pancasila pun harus dipandang sebagai satu kesatuan yang bulat dan utuh, yang tidak dapat dipisah-pisahkan. Usaha memisahkan sila-sila dalam kesatuan yang utuh dan bulat dari Pancasila akan menyebabkan Pancasila kehilangan esensinya sebagai dasar negara.

Sebagai alasan mengapa Pancasila harus dipandang sebagai satu kesatuan yang bulat dan utuh ialah karena setiap sila dalam Pancasila tidak dapat diantitesiskan satu sama lain. Secara tepat dalam Seminar Pancasila tahun 1959, Prof. Notonagoro melukiskan sifat hirarkispiramidal Pancasila dengan menempatkan sila "Ketuhanan Yang Maha Esa" sebagai basis bentuk piramid Pancasila. Dengan demikian keempat sila yang lain haruslah dijiwai oleh sila "Ketuhanan Yang Maha Esa". Secara tegas, Dr. Hamka mengatakan: "Tiap-tiap orang beragama atau percaya pada Tuhan Yang Maha Esa, Pancasila bukanlah sesuatu yang perlu dibicarakan lagi, karena sila yang 4 dari Pancasila sebenarnya hanyalah akibat saja dari sila pertama, yaitu Ketuhanan Yang Maha Esa."

Realitas pengamalan nilai Pancasila saat ini sangat menyedihkan. Pancasila hanya menjadi bahan hapalan wajib yang dibaca setiap upacara di hari Senin (maupun hari besar kebangsaan). Sedikit dari kita yang memahami bahwa Pancasila memiliki dimensi historitas, rasionalitas, dan aktualitas relevan seperti yang dipaparkan oleh cendikiawan muda Yudi Latif. Krisis hilangnya karakter dan harga diri bangsa Indonesia, memaksa kita untuk terus membumikan nilai Pancasila. Pancasila tidak hidup dalam sebuah retorika pentas politik semata. Akan tetapi, Pancasila dapat dihidupkan dalam proses pendidikan. Pendidikan mencakup dua kepentingan utama, yakni pengembangan potensi individu dan pewarisan nilai-nilai. Pendidikan memberikan transfigurasi wujud yang lebih flexible. Praktek pendidikan tidak hanya dilaksanakan di sekolah, tetapi aplikasinya juga kita temui dalam kehidupan sehari-hari.

Dalam lingkup paling sederhana, pendidikan dilaksanakan oleh lingkungan keluarga. Dengan demikian, komitmen pembelajaran pendidikan menggunakan nilai Pancasila dapat dilakukan di segala sendi kehidupan. Nilai Pancasila diharapkan mampu menumbuhkembangkan generasi muda menjadi pribadi yang utuh. Hal ini dikarenakan kepribadian yang utuh diinternalisasikan dalam sebuah kebajikan (tahu dan mau), dan terbiasa mewujudkan kebajikan itu dalam kehidupan sehari-hari.

Nilai Pancasila memberikan ruang regenerasi pemimpin bangsa yang lebih baik. Negara Indonesia merdeka bukan untuk sementara waktu tetapi selama-lamanya. Oleh karena itu, perjuangan bangsa Indonesia harus terus digalakkan. Perjuangan kita saat ini bukanlah mengangkat senjata melawan kaum imperialis. Namun, kita semua berjuang untuk menanamkan nilai Pancasila dalam kehidupan sehari-hari. Dengan demikian kita mampu bersaing, berkarya, berbangga, dan berkomitmen bersama bahwa kita adalah rakyat Indonesia.

\section{F. Penutup}

Pancasila sebagai dasar negara Indonesia yang sudah ditentukan oleh para pendiri negara ini haruslah menjadi sebuah acuan dalam menjalankan kehidupan berbangsa dan bernegara. Berbagai tantangan dalam menjalankan ideologi pancasila tidak akan mampu menggantikankan Pancasila sebagai ideologi bangsa Indonesia. Pancasila terus dipertahankan oleh segenap bangsa Indonesia sebagai dasar negara, hal tersebut membuktikan bahwa Pancasila merupakan ideologi yang sejati untuk bangsa Indonesia. Pancasila yang terdiri 
atas bagian-bagian, yaitu sila-sila Pancasila, dan setiap sila pada hakikatnya merupakan suatu asas dan fungsi sendiri-sendiri untuk tujuan tertentu, yaitu suatu masyarakat yang adil dan makmur berdasarkan Pancasila. Isi sila-sila Pancasila hakikatnya merupakan suatu ketentuan.

Pancasila dalam sudut pandang makro memiliki nilai-nilai luhur yang dapat diterapkan pada kehidupan sehari-hari. Urgensi pengamalan Pancasila dimaksudkan untuk memupuk kesadaran politik masyarakat sehingga mampu berperan aktif dalam partisipasi politik. Partisipasi masyarakat tidak dipandang sebagai sebuah formalitas, melainkan sebagai kontrol atas jalannya pemerintahan Indonesia. Hal ini menegaskan bahwa pengamalan Pancasila dapat memperbaiki praktik demokrasi Indonesia. Dengan demikian, pelaksanaan demokrasi di Indonesia dapat memajukan kepentingan bangsa dan negera Indonesia dalam rangka mewujudkan tujuan nasional.

\section{G. Daftar Pustaka}

Anderson, Benedict. (2002). Imagined Communities: Reflection on the Origin and Spread of Nationalism. Yogyakarta: Pustaka Pelajar \& Insist Press.

Arif, Saiful. (2006). Demokrasi: Sejarah, Praktik, dan Dinamika Pemikiran. Malang: Averroes Press.

As'ad, Said Alin. (2009). Negara Pancasila: Jalan Kemaslahatan Berbangsa. Jakarta: Pustaka LP3ES.

Ehrenhalt, Alan. (2006). Demokrasi Dalam Cermin: Politik. Akar Rumput dan Reformasi di Amerika Serikat. Jakarta: Yayasan Obor.
Elson. RE. (2009). The Idea Of Indonesia: Sejarah Pemikiran dan Gagasan. Jakarta: PT. Serambi Ilmu Semesta.

Brownhill, Robert dan Patricia Smart. (1989). Political Education. London and New York: Routledge.

Forrester, Geoff. (2002). Indonesia Pasca Soeharto. Yogyakarta: Tajidu Press.

Greenberg, Edward S. (2009). Political Socialization. United State Of America: Aldine Transaction.

Haris, Syamsuddin. (2014). Praktik Parlementer DemokrasiPresidensialIndonesia. Yogyakarta: Andi Publisher

Latif, Yudi. (2011). Negara Paripurna: Historisitas, Rasionalitas, Dan Aktualitas Pancasila. Jakarta: Pustaka Gramedia.

Marijan, Kacung. (2010). Sistem Politik Indonesia: Konsolidasi Demokrasi Pasca Orde Baru Jakarta: Kencana.

Somantri, Numan. (2001). Menggagas Pembaharuan Pendidikan IPS.Bandung; Remaja Rosda Karya.

Winarno. (2008). Paradigma Baru Pendidikan Kewarganegaraan. Jakarta: Bumi Aksara.

http: / / www.jimlyschool.com/read / analisis/261/konsepsi-nilai-demokratiskebersamaan-dan-ketaatan-hukumdalam-meningkatkan-pemahamannilainilai-konstitusi/. Diakses tanggal 09 Agustus 2015. 